\title{
КОМОРБІДНІСТЬ ПРИ ХРОНІЧНОМУ ОБСТРУКТИВНОМУ ЗАХВОРЮВАННІ ЛЕГЕНЬ - ГЕНДЕРНИЙ АСПЕКТ
}

\author{
Г. О. Мірошнік, А. М. Шумеляк, М. С. Люблінська, О. П. Мялюк, \\ М. I. Марущак
}

\author{
Рівненський державний базовий медичний коледж \\ ДвНЗ «Тернопільський державний медичний університет \\ імені І. Я. Горбачевського МОЗ Украӥни»
}

\begin{abstract}
У статті наведено дані про коморбідні стани при хронічному обструктивному захворюванні легень у пацієнтів віком до 60 років у гендерному аспекті. Встановлено, що хронічне обструктивне захворювання легень однаковою мірою спостерігають як у чоловіків, так і в жінок віком до 60 років із переважанням II стадії, за GOLD. Найпоширенішими коморбідними станами у пацієнтів із хронічним обструктивним захворюванням легень в дорослих осіб обох статей $€$ серцево-судинні захворювання. Хронічне обструктивне захворювання легень має несприятливий вплив на якість життя, включно емоційний та фізичний стан пацієнта, що є передумовою для активної просвітньої роботи медичного персоналу.
\end{abstract}

\section{COMORBIDITY IN CHRONIC OBSTRUCTIVE PULMONARY DISORDERS - GENDER ASPECTS}

\section{G. O. Miroshnik, A. M. Shumeliak, M. S. Lublinska, O. P. Mialiuk, M. I. Marushchak \\ Rivne Basic Medical College \\ I. Horbachevsky Ternopil State Medical University}

\begin{abstract}
The article presents data about comorbid conditions in chronic obstructive pulmonary disease in patients under 60 years in the gender aspect. It has been established that chronic obstructive pulmonary disease is equally found in both men and women under the age of 60 with a predominance of stage II, by the GOLD. The most common comorbid states in patients with chronic obstructive pulmonary disease in adults of both sexes are cardiovascular disease. Chronic obstructive pulmonary disease has an adverse effect on the quality of life, including the emotional and physical condition of the patient, which is a prerequisite for active educational work of medical staff.
\end{abstract}

Вступ. Хронічне обструктивне захворювання легень (ХОЗЛ) - це повільне прогресуюче руйнування дихальних шляхів, що характеризується поступовою втратою функції легень внаслідок поєднання хронічного бронхіту й емфіземи [1]. Глобально 10-20 \% населення понад 40 років (приблизно 80 млн осіб) страждають від хронічних захворювань, внаслідок чого щорічно помирає понад 3 млн людей. Прогнозують, що до 2020 р. ХОЗЛ стане третьою провідною причиною смерті. Сучасні дані Всесвітньої організації охорони здоров'я свідчать про те, що приблизно 210 млн осіб хворіють на ХОЗЛ, а щорічна летальність становить понад 2,75 млн людей. За смертністю досліджувана патологія в усьому світі стоїть поряд із ВІЛ/СНІД [2]. Розвиток ХОЗЛ найчастіше пов'язаний із запальною відповіддю легень на шкідливі подразники: куріння, забруднення атмосфери, професійні шкідливості [3].

Метою нашого дослідження було проаналізувати коморбідні стани при хронічному обструктивному захворюванні легень у пацієнтів віком до 60 років у гендерному аспекті.

Основна частина. Ретроспективно проаналізовано 337 історій хвороб пацієнтів, які перебували на стаціонарному лікуванні у пульмонологічному відділенні Черкаської обласної лікарні з діагнозом «хронічне обструктивне захворювання легень» протягом 2015-2016 рр.

Оцінку історій хвороб проводили шляхом вивчення паспортних та анамнестичних даних, об'єктивного обстеження, лабораторних та інструментальних методів досліджень. 
Для оцінки емоційного та фізичного стану здоров'я було включено 24 хворих на ХОЗЛ різного ступеня тяжкості, віком до 60 років, які перебували на стаціонарному лікуванні у пульмонологічному відділенні Черкаської обласної лікарні протягом 2017 р. із приводу загострення ХОЗЛ. У дослідження були включені хворі з ХОЗЛ I-IV стадій, які відповідали таким критеріям: госпіталізація в стаціонар із приводу загострення ХОЗЛ; приріст ОФВ після інгаляції $\beta_{2}$-агоністом короткої дії менше 12 \%. Було проаналізовано частоту найбільш значущих клінічних станів, які, за даними останніх досліджень, асоціюються зі зростанням ризику смерті у хворих на ХОЗЛ.

Статистичну обробку проводили за допомогою програм «Microsoft Excel» та «Statistica for Windows».

Порівнюючи середній вік хворих різної статі, які включені у дослідження, варто зазначити, що в чоловіків він становив $(48,16 \pm 1,47)$ року і практично не відрізнявся від показника у жінок $((52,32 \pm 1,84)$ року). Варто також відзначити, що у пацієнтів, віком до 60 років, переважала II стадія ХОЗЛ (58,5 \%), у меншої кількості пацієнтів було діагностовано І стадію (8,7 \%), III стадію $(27,7$ \%) і IV стадію ХОЗЛ (5,1%). По- діл пацієнтів за гендерною ознакою представлено на рисунку 1. Отримані дані вказують на практично однаковий поділ пацієнтів за стадіями ХОЗЛ у чоловіків і жінок.

Пік захворюваності на ХОЗЛ, звичайно, припадає на 55-65 років [4]. Відомо, що для цієї вікової популяції властиві поліморбідність і коморбідність [5]. На сьогодні опубліковано велику кількість результатів досліджень, які демонструють існування прямого асоціативного зв'язку між ХОЗЛ і кардіоваскулярними клінічними наслідками [6, 7]. Кардіоваскулярні захворювання у хворих на ХОЗЛ розглядають як провідні причини смертності в розвинених країнах світу та в Україні, клінічна значущість яких прогресивно зростає в міру старіння популяції [8]. Тому, ми проаналізували коморбідні стани у хворих, віком до 60 років, з ХОЗЛ.

Встановлено, що 70 пацієнтів із ХОЗЛ не мали супутньої патології, тоді як у 124 обстежених хворих, окрім хОзЛ, було ще від одного й більше захворювань, з них у 56,5 \% зареєстровано кардіологічну патологію. Поділ пацієнтів за гендерною ознакою вказує на практично однаковий поділ осіб чоловічої та жіночої статей 3 ХОзЛ та коморбідними патологіями (рис. 2).
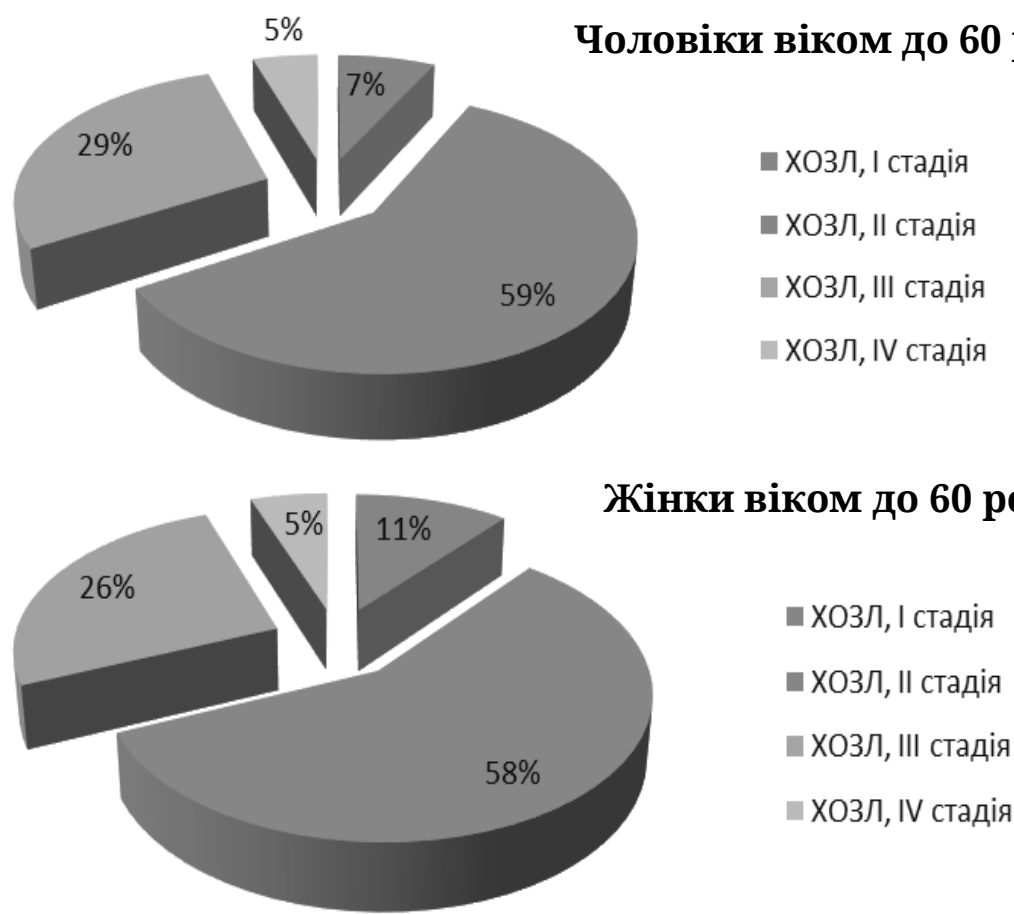

A

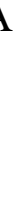

Б

\section{Рис. 1. Диференційований поділ хворих чоловічої (А) і жіночої (Б) статей залежно від стадії}

хронічного обструктивного захворювання легень.

Аналіз супутньої патології у хворих на ХОЗЛ вказує на переважання серцево-судинної патології. Так, гХ реєстрували у 2,1 \% хворих чоловічої статі І стадіїХОЗЛ, у 58,3 \% - II стадії, 33,3 \% - III стадії і в 6,3 \% хворих IV стадії ХОЗЛ. Ужінок, Хворих на ХОЗЛ, ГХ реєстрували у 4,5 \% хворих І стадії ХОЗЛ, у 50,0 \% - ІІ стадії, 31,8 \% III стадії і в 13,6 \% хворих IV стадії ХОЗЛ (рис. 3). При аналізі коморбідних станів при ХОЗЛ, у обстежених пацієнтів виявляли також цукровий діабет, захворювання шлунково-кишкового тракту та нирок.

24 ISSN 2411-1597. МЕДСЕСТРИНСТВО. 2018. № 2 
ч чоловіки, без супутньої патології

ч чоловіки з ХОзл і гХ

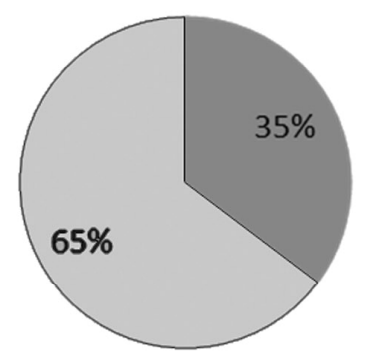

шінки, без супутньої патології

$\square$ жінки з ХОЗЛ і ГХ

РUс. 2. Диференційований поділ хворих чоловічої і жіночої статей залежно від супутнього захворювання.

\section{Чоловіки віком до 60 років}

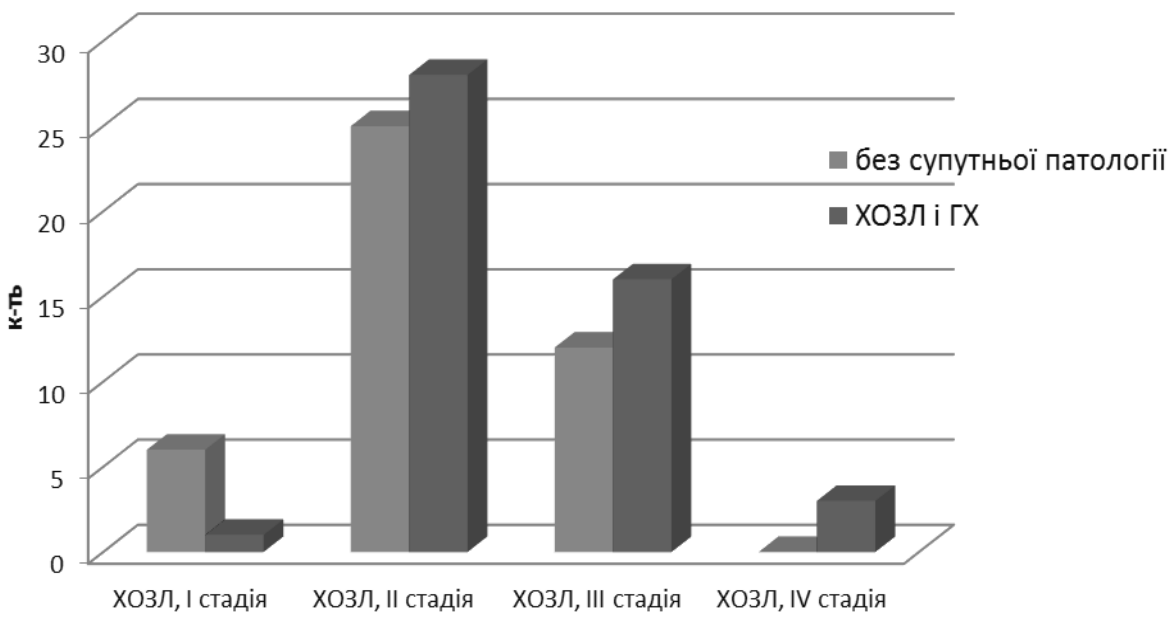

Жінки віком до 60 років

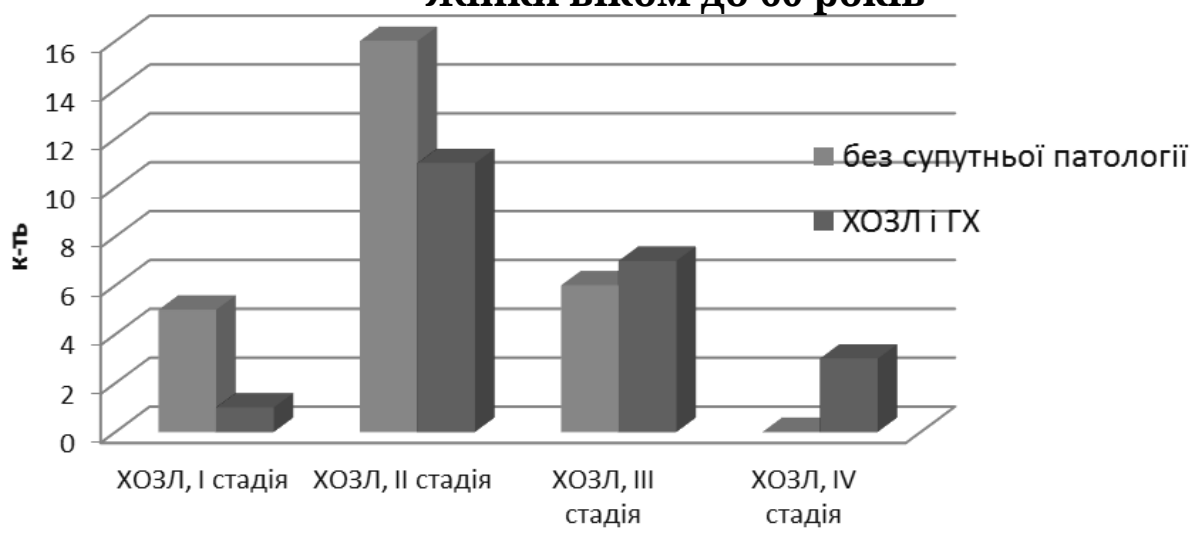

Рис. 3. Поширеність супутніх патологій у хворих на хОзл, \%.

Результати дослідження вказують на те, що хронічне обструктивне захворювання легень в дорослих осіб часто поєднується з серцево-судинною патологією.

Аналізуючи показники спірометрії, встановлено тенденцію до зниження форсованої життєвої ємності легень (ФЖЕЛ) і об'єму форсованого видиху за 1 с у пацієнтів із ХОЗЛ і ГХ, порівняно з даними пацієнтів 3 монопатологією. У пацієнтів із ХОЗЛ і ГХ достовірно вищою була пікова об'ємна швидкість видиху і миттєва об'ємна швидкість після видиху 25 \% ФЖЄЛ, що свідчить про зниження бронхіальної прохідності. Отримані дані співпадають з іншими дослідженнями, які пов'язують підвищення артеріального тиску з тяжкістю дихальної обструкції [9]. Слід зазначити, що спільним фактором ризику для ХОЗЛ і серцевосудинних захворювань може бути загальний фактор куріння, тому найбільша увага медичного персоналу має бути приділена відмові пацієнтів від куріння. 
Для оцінки самопочуття пацієнтів із ХОЗЛ і коморбідними патологіями ми поставили їм 2 запитання на предмет їх фізичного та емоційного стану: 1. Як Ви оцінюєте свій емоційний стан, настрій на теперішній час? 2. Як Ви оцінюєте свій стан здоров'я, фізичний стан на теперішній час?

Емоційний стан пацієнти оцінили по-різному. Так, пацієнти оцінили свій емоційний стан як відмінний у
4,2 \% випадків, добрий -у 33,3 \%, задовільний -у 45,8 \%, незадовільний -у 12,4\%. Відповідно, пацієнти оцінили свій фізичний стан як добрий у 29,2 \% випадків, задовільний - у 54,2 \%, незадовільний - у 12,5 \% (табл. 1).

Аналізуючи отримані дані можна стверджувати, що пацієнти пов'язують свій емоційний стан із фізичним здоров'ям.

Таблиця 1. Самооцінка емоційного та фізичного стану пацієнта, кількість

\begin{tabular}{|c|c|c|c|c|c|}
\hline & Відмінна & Добра & Задовільна & Незадовільна & $\begin{array}{c}\text { Важко } \\
\text { відповісти }\end{array}$ \\
\hline $\begin{array}{c}\text { Емоційний стан, настрій на } \\
\text { теперішній час (п=24) }\end{array}$ & 1 & 8 & 11 & 3 & 1 \\
\hline $\begin{array}{c}\text { Стан здоров'я, свій фізичний } \\
\text { стан на теперішній час (п=24) }\end{array}$ & 1 & 7 & 13 & 3 & 0 \\
\hline
\end{tabular}

Висновки. 1. Хронічне обструктивне захворювання легень однаковою мірою спостерігають як у чоловіків, так і в жінок віком до 60 років із переважанням II стадії, за GOLD. Найпоширенішими коморбідними станами у пацієнтів із хронічним обструктивним за-

\section{СПИСОК ЛІТЕРАТУРИ}

1. Longmore J. M. Oxford Handbook of Clinical Medicine. 8th ed. Oxford, UK: Oxford University Press; 2010.

2. Петров В. Г. Лікувальна фізична культура при бронхотичній формі хронічного обструктивного захворювання легенів / В. Г. Петров, О. В. Без'язична, О. В. Клітар // Фізична реабілітація та рекреаційно-оздоровчі технолоriї. - 2016. - № 2. - С. 52-53.

3. Приходько В. Ю. Хронічні обструктивні захворювання легень у людей літнього віку. Лікування загострень / В. Ю. Приходько // Семейная медицина. - 2016. № 1 (63). - С. 82-89.

4. Дворецкий Л. И. Пожилой больной ХОЗЛ: стратегия и тактика бронхолитической терапии / Л. И. Дворецкий // Пульмонология и аллергология. - 2006. - № 4. - С. 13-16.

5. Гашинова Е. Ю. Системные эффекты и коморбидность у амбулаторных пациентов с ХОЗЛ / Е. Ю. Гашинова // Український пульмонологічний журнал. - 2013. - № 2. C. 41-45.

6. Бова А. А. Хроническая обструктивная болезнь легких и ишемическая болезнь сердца: подходы к лечению хворюванням легень в дорослих осіб обох статей $\epsilon$ серцево-судинні захворювання.

2. Хронічне обструктивне захворювання легень має несприятливий вплив на якість життя, включно емоційний та фізичний стан пацієнта, що є передумовою для активної просвітньої роботи медичного персоналу.

сочетанной патологии / А. А. Бова, Д. В. Лапицкий // Клиническая медицина. - 2009. - № 2. - С. 8-13.

7. Guidelines for the Diagnosis and Management of Heart Failure in Adults: a report of the American College of Cardiology Foundation / American Heart Association Task Force on Practice Guidelines developed in collaboration with the International Society for Heart and Lung Transplantation / S. A. Hunt, W. T. Abraham, M. H. Chin [et al.] // J. Am. Coll. Cardiol. - 2009. - Vol. 53 (15). - P. 1-90.

8. Гребеник М. В. Післяінфарктне ремоделювання серця в умовах хронічної бронхіальної обструкції і шляхи його корекції : дис. ... доктора мед. наук : 14.01.02 // Гребеник Мар'ян Васильович. - Івано-Франківськ, 2008. - 310 с.

9. Особливості поєднаного перебігу хронічного обструктивного захворювання легень та гіпертонічної хвороби / Х. Я. Максів, І. В. Пірус, Р. Р. Осінчук [та ін.] // Вісник соціальної гігієни та організації охорони здоров'я України. - 2017. - № 4 (74). - С. 23-28. 